\title{
Foreign Direct Investment as a Driver of Economic Recovery and Business Innovation
}

\author{
José Manuel Macedo Botelho', Irina Maksymova ${ }^{2}$, Oleg Padalka ${ }^{3}$, Mansur Mamanazarov ${ }^{4}$, Volodymyr Kulishov ${ }^{2}$ \\ ${ }^{1}$ Business Factory, Evora 7000, Portugal \\ ${ }^{2}$ State University of Economics and Technology, Medychna street 16, Kryvyi Rih 50000, Ukraine \\ ${ }^{3}$ National Pedagogical Dragomanov University, Pyrohova str., 9., Kyiv 01601, Ukraine \\ ${ }^{4}$ National University of named after Mirzo Ulugbek, University street, 4. Tashkent city, 100174 Uzbekistan
}

\begin{abstract}
Global economy is expected to contract, consequence of a collapse of international trade with millions of failed businesses and lost jobs. Foreign Direct Investment (FDI) flows are fundamental to support the economic recovery. Developed economies and developing economies in particular must make a great effort to restore and increase capital inflows, especially in form of foreign direct investment. FDI inflows have long been the largest source of finance investment. FDI is an opportunity to support the crucial economic recovery. An internationalization model of FDI is built in order to be a driver to governments and firms to implement a success strategy to attract FDI to the country
\end{abstract}

\section{Introduction}

The COVID-19 pandemic increased the number of poor people in the world as no crisis had done before $[1,2]$. The economic crisis of 2020 had a big impact on businesses, families and put social protection and health systems at risk. The catastrophe also had serious impacts on the Fourth Industrial Revolution, on the digital economy, on human capital and underlined the gap between the economy and society [2].

The global economy is expected to drop by an impressive $4.3 \%$ in 2020 . Millions of workers and people living on a livelihood are at risk and about 130 million people will fall into extreme poverty if the economic crisis perseveres [3].

Governments must define the short and long-term policies to support the health and social system and as well the businesses activities and families [4].

Governments must define short and long-term policies to support the health and social system as well as business and family activities [4]. The emerging market and developing economies need additional support due to their economic weakness in trade, in the social and health system and, especially, those that depend on tourism and exports. [4].

The recovery must be supported by countries and the international community after the health crisis has passed [4]. Policy choices should generate new investments in productive infrastructure, in digital economy and an increase of cash incentives for social protection for the families [1].

International trade collapsed in 2020 in developed and developing economies [1]. Major economies should support developing economies in order to bridge the gap between their economies caused by the
COVID-19 crisis. International trade has a fundamental role in stimulating economic recovery [1]. However, the big question is the way how countries will balance the measures of recovery to achieve the 2030 Agenda for Sustainable Development's socio-economic growth goals [3].

FDI has fallen in the COVID-19 pandemic and is expected to decline further in 2021 and only begin to recover in 2022 [3]. The Organization for Economic Cooperation and Development (OECD) identifies a $50 \%$ decrease in global FDI in first semester of 2020 (comparatively to the second semester of 2019), the lowest level since 2013 [5] and United Nations Conference on Trade and Development (UNCTAD) predicts a drop of at least $40 \%$ [3].

\section{Literature Review}

The Second World War took place between 1939 and 1945 and since then there has been no crisis like the COVID-19 crisis with a major impact on emerging market and developing economies, the biggest recession in 60 years [6].

FDI is fundamental to the economic recovery of developing economies. Therefore, developing economies have to strain to increase FDI because FDI is the key to supporting the development of developing economies. It will be fundamental for a post COVID19 recovery [6]. With the right policies FDI can provide financial stability and boost economic wellbeing for the benefit of businesses activities and families [26].

In particular, FDI has the advantage of being a catalyst for the transfer of technology and know-how from one economy to another and to the host economy 
allows products to be boosted in international markets [13].

This article highlights a review of the empirical studies on FDI in order to explain the geographic distribution of FDI flows worldwide.

Botelho [7] made a systematization of the most relevant studies of the determinants of FDI since 2000. The study presents the author of the study divided in three dimensions: economic, institutional and business facilitators (table 1).

Table 1. Systematization of FDI determinants

\begin{tabular}{|c|c|c|c|c|}
\hline \multirow{2}{*}{$\begin{array}{l}\text { Researchers } \\
\text { (first author) }\end{array}$} & \multirow[t]{2}{*}{ Year } & \multicolumn{3}{|c|}{ Dimensions } \\
\hline & & 1 & 2 & 3 \\
\hline Villaverde, J. & 2015 & $\mathrm{a}$ & & \\
\hline Acheampong, P. & 2014 & $\mathrm{a}$ & $\mathrm{a}$ & \\
\hline Anuchitworawong, C. & 2014 & $\mathrm{a}$ & & \\
\hline Hoang, $\mathrm{H}$. & 2014 & $\mathrm{a}$ & & \\
\hline Hui, E. & 2014 & $\mathrm{a}$ & & \\
\hline Jeong, H.-G. & 2014 & $\mathrm{a}$ & $\mathrm{a}$ & $\mathrm{a}$ \\
\hline Jiao, P. & 2014 & $\mathrm{a}$ & & \\
\hline Kersan-Škabić, I. & 2014 & $\mathrm{a}$ & & \\
\hline Kowalewski, O. & 2014 & $\mathrm{a}$ & & \\
\hline Liu, K. & 2014 & $\mathrm{a}$ & & \\
\hline Penfold, M. & 2014 & $\mathrm{a}$ & $\mathrm{a}$ & \\
\hline Sánchez-Martín & 2014 & $\mathrm{a}$ & $\mathrm{a}$ & \\
\hline Tang, C. & 2014 & $\mathrm{a}$ & & \\
\hline Gamboa, O. & 2013 & $\mathrm{a}$ & & \\
\hline $\mathrm{Hu}, \mathrm{Y}$. & 2013 & $\mathrm{a}$ & & \\
\hline Ibrahim, O. & 2013 & $\mathrm{a}$ & & $\mathrm{a}$ \\
\hline Kokouma, D. & 2013 & $\mathrm{a}$ & $\mathrm{a}$ & \\
\hline Larimo, J. & 2013 & $\mathrm{a}$ & & \\
\hline Rivera, C. & 2013 & $\mathrm{a}$ & & \\
\hline Tintin, C. & 2013 & $\mathrm{a}$ & $\mathrm{a}$ & \\
\hline Bilgili. F. & 2012 & $\mathrm{a}$ & & \\
\hline Liargovas, $\mathrm{P}$. & 2012 & $\mathrm{a}$ & $\mathrm{a}$ & \\
\hline Merková, M. & 2012 & $\mathrm{a}$ & & \\
\hline Reschenhofer & 2012 & $\mathrm{a}$ & & \\
\hline Sharma, K. & 2012 & $\mathrm{a}$ & & \\
\hline Solomon, B. & 2012 & $\mathrm{a}$ & & \\
\hline Staats, J. & 2012 & & & $\mathrm{a}$ \\
\hline Tembe, $\mathrm{P}$. & 2012 & $\mathrm{a}$ & & \\
\hline Uwubanmwen A. & 2012 & $\mathrm{a}$ & & $\mathrm{a}$ \\
\hline Baek, K. & 2011 & $\mathrm{a}$ & & \\
\hline Liu, K. & 2011 & $\mathrm{a}$ & & \\
\hline Ali Khrawish, H. & 2010 & $\mathrm{a}$ & & $\mathrm{a}$ \\
\hline Ali, F. & 2010 & $\mathrm{a}$ & $\mathrm{a}$ & \\
\hline Azam, M. & 2010 & $\mathrm{a}$ & & \\
\hline Bellak, C. & 2010 & $\mathrm{a}$ & & \\
\hline Casi, L. & 2010 & $\mathrm{a}$ & & \\
\hline Choong, C.- K. & 2010 & $\mathrm{a}$ & & \\
\hline Lin, F.-J. & 2010 & $\mathrm{a}$ & & \\
\hline Sharma, K. & 2010 & $\mathrm{a}$ & $\mathrm{a}$ & \\
\hline Van Wyk, J. & 2010 & $\mathrm{a}$ & & $\mathrm{a}$ \\
\hline Dumludag, D. & 2009 & $\mathrm{a}$ & $\mathrm{a}$ & \\
\hline Ledyaeva, S. & 2009 & $\mathrm{a}$ & & \\
\hline Ang, J. B. & 2008 & $\mathrm{a}$ & & \\
\hline Bitzenis, A. & 2007 & $\mathrm{a}$ & & \\
\hline Wijeweera, A. & 2007 & $\mathrm{a}$ & & \\
\hline
\end{tabular}

\begin{tabular}{|c|c|c|c|}
\hline Hadjit, A. & 2006 & $\mathrm{a}$ & \\
\hline Ramirez, M. D. & 2006 & $\mathrm{a}$ & \\
\hline Dar, H. & 2004 & $\mathrm{a}$ & $\mathrm{a}$ \\
\hline Janicki, H. P. & 2004 & $\mathrm{a}$ & \\
\hline Cheng, L. K. & 2000 & $\mathrm{a}$ & \\
\hline \multicolumn{4}{|c|}{$\begin{array}{l}\text { Legend: 1-Economic; 2-Institutional; 3-Business } \\
\text { Facilitators. }\end{array}$} \\
\hline
\end{tabular}

«The systematization of studies presented (table 1) divides the determinants into: economic, institutional and business facilitators. Villaverde \& Maza (2015), Anuchitworawong \& Thampanishvong (2014), Hoang \& Goujon (2014), Hui \& Chan (2014), Jiao \& Jian (2014), Kersan-Škabić \& Tijanić (2014), Kowalewski \& Radło (2014), Liu et al. (2014), Tang et al. (2014), Gamboa (2013), Hu (2013), Larimo \& Arslan (2013), Rivera \& Castro (2013), Bilgili et al. (2012), Merková et al. (2012), Reschenhofer et al. (2012), Sharma et al. (2012), Solomon \& Ruiz (2012), Tembe \& Xu (2012), Baek \& Qian (2011), Liu \& Daly (2011), Azam (2010), Bellak et al. (2010), Casi \& Resmini (2010), Choong \& Lam (2010), Lin (2010), Ledyaeva (2009), Ang (2008), Bitzenis (2007), Wijeweera et al. (2007), Hadjit \& Moxon-Browne (2006), Ramirez (2006), Janicki \& Wunnava (2004) and Cheng \& Kwan (2000) developed studies on the determinants of FDI in countries or sectors of activity and concluded that the economic determinants that contributed to attracting FDI are the following: market size, market growth, market opening, agglomeration, taxes, qualified labor, economic stability (inflation), exports, natural resources and external indebtedness. Acheampong \& Osei (2014), Jeong (2014), Penfold (2014), SánchezMartín et al. (2014), Kokouma \& Xu (2013), Tintin (2013), Liargovas \& Skandalis (2012), Ali et al. (2010), Sharma \& Bandara (2010), Dumludag (2009) and Dar et al. (2004) identified in their investigations, in addition to the economic determinants already mentioned, institutional determinants (control of corruption, government effectiveness, political stability, normative quality, rule of law and voice and responsibility) that contributed to attracting FDI. Jeong (2014), Ibrahim \& Hassan (2013), Staats \& Biglaiser (2012), Uwubanmwen \& Ajao (2012), Ali Khrawish \& Zakaria (2010) and Van Wyk \& Lal (2010) considered that facilitators of doing business are crucial to attracting FDI» (Botelho, 2015) [7].

The United Nations published an international investment framework/structure [26] that explains the differences in FDI inflows among countries and formulates policies to capture inbound investment, based in Transnational Corporations investment. The principal determinants of the location of FDI are divided in three dimensions: the policies made by governments and institutions to influence the attraction of FDI, the economic determinants and the business facilitators (table 3).

The Support Structure to FDI policy is made by governments and institutions and consists in a political, economic and social principles and measures that drive to a stability environment to attract FDI, regulations to 
ingress and operations, rules for functioning of markets, FDI international agreements, privatization policy, trade policy and tax policy [26]. Policies can prohibit the entry of FDI into a market and can make rules and regulations on the treatment of nondiscrimination between domestic and foreign companies - and can also regulate the special treatment of foreign companies [26]. Policies can achieve a number of objectives to increase or decrease FDI inflows, such as investing in identified sectors of the economy, the country's origin of FDI and how FDI contributions are made [26]. FDI policies are generally associated with other policies to influence investors decisions to achieve the same results. However, the Support Structure to FDI policy is becoming less important because almost all countries are having the same strategy [26].

Instead, business facilitators are becoming relatively more important than the investment policy. They include investment incentives, post investment services and measures to minimize the «hassle costs» (related to corruption and efficiency of administrative processes) in the business environment. This set of measures aims to be more competitive in attracting FDI, since with the opening of markets, the country's policies are becoming similar. In addition, the country's policy measures are being more complex to reach private investors giving them business facilitators to attract investment [26].

After implementing the Support Structure to FDI policy, the economic factors are the most important dimension to attract FDI inflows. Economic factors have three motivations to attract FDI, the marketsearching, the resource/asset searching and efficiencysearching (table 3) [26].

The pandemic crisis is expected to hardly affect developing countries, especially in Africa. Africa has 13 percent of the world's population and had more than 50 percent of world's extreme poverty in 2020. Least developed countries are expected to increase the number of poor by 33.4 million in 2020 and a change in the proportion of headcount ratio of 3.16 percent, based on the $\$ 1.90$ per day poverty rate table 2) [3].

Table 2. Estimated changes in extreme poverty in 2020

\begin{tabular}{|l|c|c|}
\hline & $\begin{array}{c}\text { Change in } \\
\text { headcount ratio } \\
\text { (\%) }\end{array}$ & $\begin{array}{c}\text { Change in } \\
\text { number of poor } \\
\text { (millions) }\end{array}$ \\
\hline $\begin{array}{l}\text { East Asia and } \\
\text { the Pacific }\end{array}$ & 0.21 & 4.41 \\
\hline $\begin{array}{l}\text { Europe and } \\
\text { Central Asia }\end{array}$ & 0.23 & 1.16 \\
\hline $\begin{array}{l}\text { Latin America } \\
\text { and the } \\
\text { Caribbean }\end{array}$ & 0.55 & 3.58 \\
\hline $\begin{array}{l}\text { Miidle East } \\
\text { and North } \\
\text { Africa high }\end{array}$ & 1.22 & 4.91 \\
\hline $\begin{array}{l}\text { Other } \\
\text { income }\end{array}$ & 0.01 & 0.07 \\
\hline South Asia & 1.25 & 23.28 \\
\hline $\begin{array}{l}\text { Sub-Saharan } \\
\text { Africa }\end{array}$ & 2.74 & 31.17 \\
\hline Least & 3.16 & 33.4 \\
\hline
\end{tabular}

\begin{tabular}{|l|c|c|}
\hline $\begin{array}{l}\text { developed } \\
\text { countries }\end{array}$ & & \\
\hline World Total & $\mathbf{0 . 8 8}$ & $\mathbf{6 8 . 5 7}$ \\
\hline
\end{tabular}

Source: UNCTAD, 2020 [3]

Table 3. Framework to FDI Attraction Determinants

\begin{tabular}{|c|c|c|}
\hline $\begin{array}{l}\text { Host country } \\
\text { determinants }\end{array}$ & $\begin{array}{l}\text { FDI by } \\
\text { factors }\end{array}$ & $\begin{array}{l}\text { FDI Economic } \\
\text { determinants in } \\
\text { recipient countries }\end{array}$ \\
\hline $\begin{array}{l}\text { I. Support } \\
\text { Structure to FDI } \\
\text { Policy }\end{array}$ & $\begin{array}{l}\text { A. Market- } \\
\text { searching }\end{array}$ & - size of the market \\
\hline $\begin{array}{l}\text { - political, } \\
\text { economic, and } \\
\text { social stability }\end{array}$ & & - market growth \\
\hline $\begin{array}{l}\text { - regulations to } \\
\text { ingress and } \\
\text { operations }\end{array}$ & & $\begin{array}{l}\text { - enter in markets } \\
\text { (regional and } \\
\text { global) }\end{array}$ \\
\hline $\begin{array}{l}\text { - rules for } \\
\text { functioning of } \\
\text { markets }\end{array}$ & & $\begin{array}{l}\text { - country consumer } \\
\text { preferences }\end{array}$ \\
\hline $\begin{array}{l}\text { - FDI international } \\
\text { agreements }\end{array}$ & & $\begin{array}{l}\text { - structure of } \\
\text { markets }\end{array}$ \\
\hline $\begin{array}{l}\text { - privatization } \\
\text { policy }\end{array}$ & $\begin{array}{l}\text { B. } \\
\text { Resource/as } \\
\text { set- } \\
\text { searching }\end{array}$ & - raw materials \\
\hline $\begin{array}{l}\text { - trade policy } \\
\text { (tariffs and non- } \\
\text { tariff barriers) }\end{array}$ & & $\begin{array}{l}\text { - low-cost unskilled } \\
\text { labour }\end{array}$ \\
\hline - tax policy & & - skilled labour \\
\hline $\begin{array}{l}\text { II. Economic } \\
\text { determinants }\end{array}$ & & $\begin{array}{l}\text { - assets with } \\
\text { advanced and } \\
\text { innovative } \\
\text { technologies }\end{array}$ \\
\hline $\begin{array}{l}\text { III. Business } \\
\text { facilitators }\end{array}$ & & $\begin{array}{l}\text { - infrastructures } \\
\text { (ports, roads, power, } \\
\text { telecommunication) }\end{array}$ \\
\hline $\begin{array}{l}\text { - incentives and } \\
\text { investment } \\
\text { promotion }\end{array}$ & $\begin{array}{l}\text { C. } \\
\text { Efficiency- } \\
\text { searching }\end{array}$ & $\begin{array}{l}\text { - cost of assets listed } \\
\text { in B }\end{array}$ \\
\hline $\begin{array}{l}\text { - after-investment } \\
\text { services }\end{array}$ & & $\begin{array}{l}\text { - other costs } \\
\text { (transport and } \\
\text { communication } \\
\text { costs) }\end{array}$ \\
\hline $\begin{array}{l}\text { - hassle costs } \\
\text { (related to } \\
\text { corruption, } \\
\text { efficiency of } \\
\text { administrative } \\
\text { processes, etc.) }\end{array}$ & & $\begin{array}{l}\text { - associated of a } \\
\text { regional corporate } \\
\text { network }\end{array}$ \\
\hline
\end{tabular}

Source:[26]

\section{Methodology}

This research aims to identify the economic determinants that attract FDI and proposes an internationalization model that will be a future reference to implement internationalization strategies 
for governments, institutions, agencies and companies, that will contribute to the economic recovery using foreign investment as a motivator to do so.

The study is based in the review of empirical studies and has the purpose of find out what are the determinants of FDI, in order to discover the motivations that companies are looking for investment.

This study adopts the literature review research method. The research includes a systematization of the study of FDI determinants with 50 empirical studies on different countries around the world that differ in size, economic development, business environment, governance, infrastructure, trade openness, location and the identification of the main determinants that attract FDI. A qualitative approach will be adopted in the present study given the current context and the scope of the research. A qualitative research is more suitable for the study due to the distinct objective of providing a complete understanding and interpretation of a phenomenon [9].

Data used for the research comes from a variety of sources that includes various academic journals, books and publications.

\subsection{Opportunities and Challenges to support Recovery}

The COVID-19 crisis had a negative impact on the world project finance presented with consequences in the decline of FDI (table 4). In Developing Countries, between 2015-2019 projects of 417.7 billion of dollars were presented when in the period of 2010-2014 projects of 616.1 billion of dollars were presented, a decrease of -198.4 billion of dollars $(-32 \%$ of investment).

The biggest drop was in the Power sector where the value of the investment was 73.4 billion dollars in the 2015-2019 period, a reduction of -89.4 billion dollars ($55 \%$ ), compared to the period 2010-2014 where the investment amounted was 162.8 billion dollars (table $4)$.

Table 4. Project Finance by sectors (Developing Countries)

\begin{tabular}{|c|c|c|c|}
\hline & \multicolumn{2}{|c|}{$\begin{array}{r}\text { Announced projects } \\
\text { (billion dollars) }\end{array}$} & \multirow[t]{2}{*}{$\begin{array}{c}\text { Change } \\
(\%)\end{array}$} \\
\hline & $\begin{array}{l}2010- \\
2014\end{array}$ & $2015-2019$ & \\
\hline Total & 616.1 & 417.7 & -32 \\
\hline $\begin{array}{ll}\begin{array}{l}\text { Number } \\
\text { projects }\end{array} & \text { of } \\
\end{array}$ & 478 & 676 & 42 \\
\hline $\begin{array}{l}\text { Power (excluding } \\
\text { renewable energy) }\end{array}$ & 162.8 & 73.4 & -55 \\
\hline $\begin{array}{l}\text { Number } \\
\text { projects }\end{array}$ & 144 & 117 & -19 \\
\hline $\begin{array}{l}\text { Climate change } \\
\text { mitigation }\end{array}$ & 117.3 & 125.7 & 7 \\
\hline $\begin{array}{l}\text { Number } \\
\text { projects }\end{array}$ & 80 & 334 & 318 \\
\hline Transport services & 310.2 & 191.6 & -38 \\
\hline $\begin{array}{l}\text { Number } \\
\text { projects }\end{array}$ & 209 & 178 & -15 \\
\hline $\begin{array}{l}\text { Tele } \\
\text { communications }\end{array}$ & 8 & 4 & -50 \\
\hline
\end{tabular}

\begin{tabular}{|lr|c|c|c|}
\hline $\begin{array}{l}\text { Number } \\
\text { projects }\end{array}$ & of & 10 & 8 & -22 \\
\hline $\begin{array}{l}\text { Water } \\
\text { sewerage }\end{array}$ & and & 17.8 & 23.0 & 29 \\
\hline $\begin{array}{l}\text { Number } \\
\text { projects }\end{array}$ & of & 35 & 41 & 17 \\
\hline
\end{tabular}

Source: UNCTAD, 2020 [3]

In the Least Developed Countries case (table 5), between 2015-2019 projects of 33.5 billion of dollars were presented when in the period of 2010-2014 projects of 41.7 billion of dollars were presented, a decrease of -8.2 billion of dollars $(-20 \%$ of investment).

The biggest drop was in the Transport services sector where the value of the investment was 9.9 billion dollars in the 2015-2019 period, a reduction of 13.1 billion dollars $(-57 \%)$, compared to the period 2010-2014 where the investment amounted was 23 billion dollars.

Table 5. Project Finance by sectors (Least Developed Countries)

\begin{tabular}{|c|c|c|c|}
\hline & \multicolumn{2}{|c|}{$\begin{array}{r}\text { Announced projects } \\
\text { (billion dollars) }\end{array}$} & \multirow[t]{2}{*}{$\begin{array}{c}\text { Change } \\
(\%)\end{array}$} \\
\hline & $\begin{array}{c}2010- \\
2014\end{array}$ & $2015-2019$ & \\
\hline Total & 41.7 & 33.5 & -20 \\
\hline $\begin{array}{l}\text { Number } \\
\text { projects }\end{array}$ & 40 & 79 & 99 \\
\hline $\begin{array}{l}\text { Power (excluding } \\
\text { renewable } \\
\text { energy) }\end{array}$ & 6.7 & 9.5 & 41 \\
\hline $\begin{array}{l}\text { Number } \\
\text { projects }\end{array}$ & 13 & 18 & 37 \\
\hline $\begin{array}{l}\text { Climate change } \\
\text { mitigation }\end{array}$ & 11.5 & 13 & 13 \\
\hline $\begin{array}{ll}\text { Number } & \text { of } \\
\text { projects } & \\
\end{array}$ & 15 & 39 & 170 \\
\hline $\begin{array}{l}\text { Transport } \\
\text { services }\end{array}$ & 23 & 9.9 & -57 \\
\hline $\begin{array}{ll}\begin{array}{l}\text { Number } \\
\text { projects }\end{array} & \text { of } \\
\end{array}$ & 10 & 18 & 88 \\
\hline $\begin{array}{l}\text { Tele } \\
\text { communications }\end{array}$ & 0.3 & 0.5 & 85 \\
\hline $\begin{array}{ll}\text { Number } & \text { of } \\
\text { projects } & \\
\end{array}$ & 1 & 1 & -29 \\
\hline $\begin{array}{ll}\text { Water } & \text { and } \\
\text { sewerage } & \end{array}$ & 0.2 & 0.6 & 142 \\
\hline $\begin{array}{ll}\text { Number } & \text { of } \\
\text { projects }\end{array}$ & 1 & 2 & 200 \\
\hline
\end{tabular}

Source: UNCTAD, 2020 [3]

These indicators highlight a decrease in the number of projects presented compared to previous trends before the 2015-2019 period, where the marked sectors grew more than 40 percent compared to the 2010-2014 period.

In the 2015-2019 period, the global value of projects decreased -32 percent in developing countries and -20 percent in least developed countries, especially due to the reduction in the size of projects in sectors such as energy.

Despite negative trends, investment in public health and the digital economy can be increased now and in the medium term. The European Investment Bank 
announced an agreement with the World Health Organization to strengthen financial support for the needs of the COVID-19 crisis.

These investments have the health system and the primary health-care services target in low-income and middle-income countries. The World Health Organization strategy is to develop diagnostic tests and vaccines for COVID-19 treatment [3].

Another challenge is to support the most dependent countries, those that depend on Official Development inflows, Remittances and FDI inflows (table 6).

Table 6. Most dependent countries on official assistance, remittances and FDI inflows (2019)

\begin{tabular}{|c|c|c|c|}
\hline & $\begin{array}{l}\text { Net Official } \\
\text { Development } \\
\text { Assistance } \\
\text { inflows } \\
(2018) \\
\end{array}$ & $\begin{array}{c}\text { Remittances } \\
\text { (2019) }\end{array}$ & $\begin{array}{c}\text { FDI } \\
\text { inflows } \\
(2019)\end{array}$ \\
\hline \multicolumn{4}{|c|}{ Millions of dollars } \\
\hline $\begin{array}{l}\text { Least } \\
\text { developed } \\
\text { countries }\end{array}$ & & & \\
\hline Tuvalu & 19 & 4 & 0.3 \\
\hline$\%$ of $G D P$ & $44 \%$ & $10 \%$ & $0.7 \%$ \\
\hline Kiribati & 74 & 20 & 0.5 \\
\hline$\%$ of $G D P$ & $38 \%$ & $10 \%$ & $0.3 \%$ \\
\hline $\begin{array}{l}\text { Central } \\
\text { African } \\
\text { Republic }\end{array}$ & 656 & .. & 26 \\
\hline$\%$ of $G D P$ & $30 \%$ & & $1.1 \%$ \\
\hline Yemen & 7985 & 3771 & -371 \\
\hline$\%$ of $G D P$ & $29 \%$ & $14 \%$ & $-1.2 \%$ \\
\hline Afghanistan & 3789 & 804 & 39 \\
\hline$\%$ of $G D P$ & $19 \%$ & $4 \%$ & $0.2 \%$ \\
\hline \multicolumn{4}{|l|}{$\begin{array}{l}\text { Other } \\
\text { developing } \\
\text { countries }\end{array}$} \\
\hline Palau & 84 & 2 & 22 \\
\hline$\%$ of $G D P$ & $30 \%$ & $1 \%$ & $7.6 \%$ \\
\hline Nauru & 32 & 7 &.. \\
\hline$\%$ of $G D P$ & $25 \%$ & $5 \%$ & .. \\
\hline $\begin{array}{l}\text { Micronesia } \\
\text { (Federated } \\
\text { States of) }\end{array}$ & 99 & 23 & .. \\
\hline$\%$ of $G D P$ & $25 \%$ & $6 \%$ & .. \\
\hline $\begin{array}{l}\text { Marshall } \\
\text { Islands }\end{array}$ & 54 & 31 & 4 \\
\hline$\%$ of $G D P$ & $24 \%$ & $14 \%$ & $1.9 \%$ \\
\hline Tonga & 87 & 183 & 13 \\
\hline$\%$ of $G D P$ & $19 \%$ & $41 \%$ & $2.4 \%$ \\
\hline
\end{tabular}

The Official Development Assistance and Remittances have a huge importance in support the least developed countries and other developing countries as the table 6 shows. Some of these countries attract a few FDI inflows and they depend on the Official Development Assistance and Remittances, so they must be supported by the policies designed [3]

Governments must adapt their policies to respond quickly to the COVID-19 crisis. These actions must be effective in developing countries supporting short-term research and development and fiscal measures and also a long duration strategy. The moment has the opportunity to increase cooperation among countries, especially between developed and developing countries, to share technology and innovation through the creation of a network of centres of scientific excellence [3].

Government policies must pay special attention to the e-commerce sector to implement reforms and adequate investments to reach their potential. An UNCTAD research says that most of governments have e-commerce strategies and want to share them with their partners to increase digital compliance [3].

Cooperation should gather together various entities such as governments, international non-governmental organizations, research and development agencies and the private sector to increase digital commerce and outline a beneficial group strategy. Collaboration between small and large companies is essential to create an innovation environment, exploring new innovation models that strengthen companies' competitive advantages. Developing countries must build new innovation centres where they can concentrate all the knowledge involved in innovation and pay special attention to learn, assimilate and decentralize knowledge and technologies to other partners and to the market. Research and Development (R\&D) plays a key role in responding to the health, economic and social consequences of the COVID-19 crisis [3].

\subsection{Model}

Economic factors are the most important category as locational FDI determinants [22]. This study takes as a conceptual anchor the most important FDI economic determinants namely natural resources, market size, growth market, market openness, skilled labour, education system, tax policy and innovation.

Natural resources. Looking back on history and more specifically in the 19th century, natural resources, mainly minerals and primary products for the industrialized countries of Europe and North America, have become the most important determinant of FDI. In the 20th and 21st centuries, natural resources remain important but the importance of the primary sector was overtaken by the secondary and tertiary sectors [26].

Dunning's eclectic theory holds that countries with more natural resources attract more FDI. Companies can increase their competitiveness by investing in markets that have higher quality natural resources and at a lower real cost than in the country of origin. This motivation is more important in the case of industrial companies that need to ensure low production costs and continuous sources of supply [12]. A set of empirical studies confirms natural resources as a determinant of FDI $[10,11,16,17]$.

Market size and growth. The size of a market is one of the main reasons that attract FDI, considering the size and population of that market. Large markets may have more companies which gives them greater benefits from economies of scale. [26]. Several studies $[14,21]$ concluded about the relevance of market size and market growth as a reason of attraction of FDI. 
Innovation. Policies to increase investment in innovation systems are fundamental due to the creation of new assets [23].

Several studies $[15,23,25]$ found evidence that the innovation is a determinant of attraction of FDI.

An internationalization model is built to support the strategy of economic recovery (figure 1).

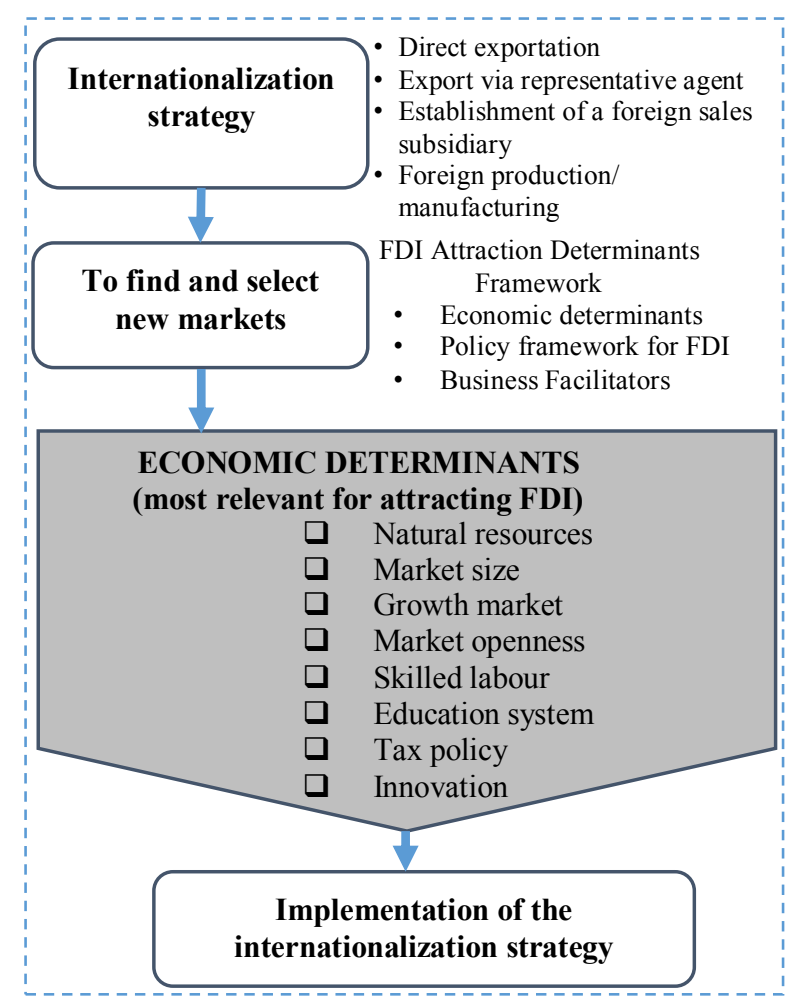

Fig. 1. Internationalization Model for Economic Recovery

Source: Made by the authors of the article

FDI flows are crucial to economic recovery in developed and developing economies. The Internationalization Model is an international reference framework to encourage FDI in economies affected by the crisis.

The first step in the Internationalization Model is to define the internationalization strategy which could be direct exportation, export via independent representative, establishment of a foreign sales subsidiary or investing in foreign production/manufacturing.

The second step in the Internationalization Model is to find and select new markets based in the Framework to FDI Attraction Determinants where the economic factors are the most important determinants [26] to attract FDI in host countries.

The Frame of Reference to FDI Attraction Determinants developed by UNCTAD has three dimensions (Economic factors, Support Structure to FDI Policy and Business facilitators). The Support Structure to FDI Policy and the Business facilitators are dimensions that are very similar in the context of the liberalization and globalization among countries and the Economic determinants become the most important determinants for attracting FDI.
The most important Economic determinants that must be analyzed by governments, institutions and companies, by each entity separately or by the various entities together, to find and select new markets are natural resources, market size, growth market, market openness, skilled labour, education system and tax policy. The countries that have the best indicators should be the selected.

The third step is to implement the internationalization strategy in the markets, previously selected, preferably by a strategic group formed by interests at national, sectorial and business level.

\section{Conclusions}

Due to a huge unpredictability, it is impossible to predict the consequences of the government policies on the economy. However, the economic recovery is going to happen in a short or medium term as the vaccination in the world against COVID-19 progresses.

The enormous task faced by national governments is to find the right solutions on national, industry and firm level. Economic activities seriously affected in some sectors, like tourism, should be replaced by secure activities with economic viability.

In future, the pandemic crisis will have multiple damage in several channels, in human capital due to closure of businesses, in the education system due to the loss of schooling, in the foreign investment due to a lower demand and a lower investment.

This study gives to governments, institutions and firms an internationalization model for attraction of FDI, that incorporates a Support Structure of FDI Policy, Business facilitators and the more important factors to support the attraction of FDI, the economic determinants, to help and accelerate the economic recovery.

\section{References}

1. Malpass, D. (2021). World Bank Group President. Countries Can Take Steps Now to Rebuild from COVID-19 Available at:

https://www.worldbank.org/en/news/pressrelease/2020/06/02/countries-can-take-steps-nowto-speed-recovery-from-covid-19, accessed in 11.01.2021.

2. Schwab, K. (2020). World Economic Forum. The Global Competitiveness Report Special Edition 2020: How Countries are Performing on the Road to Recovery. Available at:

https://www.weforum.org/reports/the-globalcompetitiveness-report-2020, accessed in 11.01.2021.

3. UNCTAD (2020). United Nations Conference on Trade and Development. Pandemic on trade and development. Transitioning to a new normal. Available at: https://unctad.org/system/files/officialdocument/osg2020d1_en.pdf, accessed in 12.01.2021. 
4. WB (2020). World Bank. Countries Can Take Steps Now to Rebuild from COVID-19. Available at: https://www.worldbank.org/en/news/pressrelease/2020/06/02/countries-can-take-steps-nowto-speed-recovery-from-covid-19, accessed in 12.01.2021.

5. WB (2020a). World Bank. Reviving FDI flows is crucial to economic recovery in developing economies. Available at:

https://blogs.worldbank.org/voices/reviving-fdiflows-crucial-economic-recovery-developingeconomies, accessed in 13/01/2021.

6. OECD (2020). Organization for Economic Cooperation and Development. FDI in Figures October 2020. Available at: https://www.oecd.org/investment/investmentpolicy/FDI-in-Figures-October-2020.pdf, accessed in 12.01.2021.

7. Botelho, J. (2015). Internationalization of Enterprises: Contributions to Building a Model Support Analysis and Implementation Strategies for Internationalization. Doctoral dissertation. Evora University, Portugal.

8. Anuchitworawong, C. \& Thampanishvong, K. (2014). Determinants of foreign direct investment in Thailand: Does natural disaster matter? International Journal of Disaster Risk Reduction. http://dx.doi.org/10.1016/j.ijdrr.2014.09.001.

9. Ritchie, J., Lewis, J., Nicholls, C. M., \& Ormston, R. (Eds.). (2013). Qualitative Research Practice.

10. Ledyaeva, S. (2009). Spatial econometric econometric analysis of foreign direct investment determinants in Russian regions. World Economy, 32 (4), 643-666.

11. Cheung, Y.-W. \& Qian, X. (2009). Empirics of China's outward direct investment. Pacific Economic Review, 14 (3), 312-341.

12. Dunning, J. H. \& Lundan, S. (2008). Theories of foreign direct investment. in John H. Dunning and Sarianna M. Lundan (orgs.), Multinational Enterprises and the Global Economy, Cheltenham: Edward Elgar Publishing Limited, pp. 79-115.

13. OECD (2008). Organization for Economic Cooperation and Development. Benchmark Definition of Foreign Direct Investment, fourth edition. Available at: https://www.oecd.org/daf/inv/investmentstatisticsa ndanalysis/40193734.pdf, accessed in 12.01.2021.

14. Hansen, H. \& Rand, J. (2006). On the causal links between FDI and growth in developing countries. The World Economy Vol. 29, Issue 1, pages 2141, January.

15. Na, Lv and Lightfoot, W.S. (2006). Determinants of foreign direct investment at the regional level in China. Journal of Technology Management in China, Vol. 1, No 3, pp. 262-278.

16. Asiedu, E. (2005). Foreign direct investment in Africa: The role of natural resources, market size, government policy, institutions and political instability (April). University of Kansas Department of Economics. Available at SSRN: https://onlinelibrary.wiley.com/doi/abs/10.1111/j.1 467-9701.2006.00758.x, accessed in 16.01.2021.
17. Deichmann, J., Eshghi, A., Haughton, D., Sayek, S. \& Teebagy, N. (2003). Foreign direct investment in the Eurasian transition states. Eastern European Economics, vol. 41, n.1, January-February, pp. 5-34.

18. Gorter, J. \& Parikh, A. (2003). How sensitive is FDI to differences in corporate income taxation within the EU? De Economist, 151(2), pp. 193204.

19. Noorbakhsh, F., Paloni, A. \& Youssef, A. (2001). Human capital and FDI inflows to developing countries: new empirical evidence. World Development, 29 (9), pp. 1593-1610.

20. Zhang, K. H. (2001). What Attracts Foreign Multinational Corporations to China? Contemporary economic Policy, Vol. 19, No. 3, pp. 336-346.

21. Shatz, H. \& Venables, A. (2000). The geography of international investment. World Bank Policy Research Working Paper $N^{\circ}$. 2338. Available at: https://openknowledge.worldbank.org/bitstream/ha ndle/10986/18843/multi_page.pdf?sequence $=1$, accessed in 16.01.2021.

22. Lipsey, R. (2000). Inward FDI and economic growth in developing countries. Transnational Corporations, vol. $9, \mathrm{n}^{\circ} 1$, Abril.

23. OECD (2000). Main determinants and impacts of foreign direct investment on China's economy. Working papers on international investment, Number 2000/4.

24. Nicoletti, G., Scarpetta, S. \& Boylaud, O. (1999). Summary indicators of product market regulation with an extension to employment protection legislation. OECD, ECO Working Paper n 226. Available http://papers.ssrn.com/sol3/papers.cfm?abstract id $=201668$, accessed in 16.01.2021.

25. Zhang, K. \& Markusen, J. (1999). Vertical multinationals and host-country characteristics. Journal of Development Economics 59 (2): 233252.

26. UNCTAD (1998). United Nations Conference on Trade and Development. World Investment Report 1998. Trends and Determinants. Available at: https://unctad.org/system/files/officialdocument/wir1998_en.pdf, accessed in 15.01.2021. 